\title{
Finno-Ugric semiotics: Cultures and metacultures
}

\author{
Anti Randviir, Eero Tarasti, Vilmos Voigt ${ }^{1}$
}

In the framework of the Finno-Ugric Congress held in Tartu in 2000 there took place, under the Hungarian initiative, also foundation of the Finno-Ugric Semiotic Association to unite different Finno-Ugric peoples and cultures, from the semiotic viewpoint, in at least two major aspects. The first aspect is concerned with unified semiotic analysis of these cultures, whereas the second one should be concerned with organizational matters in terms of forming stabile network between the Finno-Ugric semioticians and the relevant national institutions. Since this type of organization (cf. organizations founded on the basis of so-to-speak universal objects, e.g. visual semiotics, spatial semiotics, etc.) is not common yet in the international structure of semiotics (probably with some exceptions like the Balkan region), it is probably worth introducing both from the formal viewpoint and with respect to a closer look at the semiotic activity in the three Finno-Ugric cultures having the state structure to support it (Estonia, Finland and Hungary). Within the domain of Finno-Ugric studies, semiotics appeared only during the last decades as a special field of research. Important works were published in linguistics, literary studies, musicology, art history, cultural analysis, psychology, folklore and sociology etc. from semiotic points of view. Detection of signs in different Finno-Ugric cultures became a fashionable topic. International acceptance of Finnish, Hungarian and Estonian semiotics has been overwhelming. Still, we know relatively little about semiotics among other Finno-Ugric peoples. Historic surveys are relatively frequent, but until recently there was no attempt to summarize the scope and prospects of 'Finno-Ugric semiotics'. About thirty years ago Thomas A. Sebeok, in a lecture for the audience of the

Authors' addresses: A. Randviir - Dept. of Semiotics, University of Tartu, Tiigi St. 78, 50410 Tartu, Estonia; e-mail: randviir@ut.ee; E. Tarasti — Dept. of Musicology, University of Helsinki, Vironkatu 1, 00014 Helsinki, Finland; e-mail: tarasti@helsinki.fi; V. Voigt — Dept. of Folklore, Eötvös Loránd University, Piarista köz 1, 1052 Budapest V, Hungary; e-mail: voigt@ludens.elte.hu. 
Helsinki University, spoke about the necessity of collecting data of nonverbal behavior among the Finno-Ugric peoples, including their sign systems. However, this lecture remained unpublished and thus without direct results. Thus, in accord with the trivial dynamism between the development of science and its formal structures (university departments, associations, etc.), foundation of Finno-Ugric Semiotics Association presents a good ground to ask the question why there would be any need for Fenno-Ugric semiotic studies at all.

It is a well-known fact that semiotics is as old a discipline as having its roots in Ancient Hellas, having been belonging, as a (sub)doctrine of diagnostics, to the scientific field of medicine. It is also a widespread triviality that the word 'semiotics', as having its roots in ancient terminology, in fact did survive much thanks to this quite specific area of usage. Yet again, from the contemporary semiotic viewpoint it is not customary to acknowledge survey of semiotics as such a dependent field. Instead it is more usual to rather divide the history of semiotics into roughly two periods, one of which helps semioticians to refer their history back until Antiquity, and the other one considering the end of the $19^{\text {th }}$ century as the 'true semiotics in the meaning understood in contemporary context'. This understanding, as we know, has also dissimilar points of departure: some claim contemporary semiotics to have begun with the works of F. de Saussure, others associate it with creation by C. S. Peirce. A silent background knowledge of both trends, however, acknowledges the fact that neither of the individuals can be associated with conscious positive propaganda for the birth of contemporary semiotics, for one of them was articulated practically only via his students, and the other one, in connection with quite specific biographicalhistorical circumstances, could not express his views unless pleasing the goal keepers of the time.

Thus at the first glance we could differentiate between two births of semiotics: one at its historical literary beginning in ancient Hellas, and the other one as having taken place in the end of the $19^{\text {th }}$ or in the beginning of the $20^{\text {th }}$ century. Hereby it is maybe even not that relevant what was the respective argument for the grounds of such a discipline - whether the similarity of different sign systems (Saussure) or the overall logic of human behavior (Peirce). Hurrying on ahead - the general development, or more correctly introduction of the conceptions, of 'semiotics proper' has comparative aspects for semiotic discourse in the Finno-Ugric cultures, and on the other hand it is possible to outline connections of the Finno-Ugric people(s) with the development of semiotics as a discipline (e.g. merits of the Hungarian T.A. Sebeok and others for the expansion of Peircian semiotics, and cultural semiotics as a branch of Saussure's semiology). However, if we want to give a short sketch on Finno-Ugric semiotics, the topics should include at least the following: Finno-Ugric background of native semiotic terms; semantic development and recent status of terms denoting the 'scientific study of signs' in the FinnoUgric perspective; native-cultural semiotic discourse; recent 'schools', 
'trends' and 'circles' in Finno-Ugric semiotics and their research history; and finally of course also future tasks and perspectives.

If we leave for a moment the metalevel of description, we immediately recognize that at the same time the above mentioned two major contemporary semiotic theories were molded, there were shaped also those semiotic concepts that were quite directly connected with the general movement of formation of nation states in Europe; and the latter were most definitely semiotic. It does not even seem important whether the national movements leading finally to contemporary order of Europe (and that much of the world in general) were national in the today's recognized meaning, but they definitely took many semiotic structures as those through which to differentiate between dissimilar cultures. Suchlike semiotic structures often included language, way of life, behavioral patterns, image-schemas, and the similar - and it is noteworthy that this has been alike also on the metalevel (e.g. C. Kluckhohn's outstanding treatment [that was actually roughly simultaneous with trials of defining culture by O. Loorits, an Estonian cultural philosopher, to be taken up below]). During the radical development of the foundations of contemporary semiotics as a discipline, the general cultural development of several nations was essentially reflective and semiotic as well.

\section{Traces of the semiotic vocabulary and the Hungarian as the oldest}

Let us first consider the Finno-Ugric background of the respective native semiotic terms. Hungarian jel/jegy, the basic term in semiotics, occurs in historical manuscripts from 1416/1224 on. Its meaning is 'sign', and medieval sources contain verbs or derivatives from it (together with scholarly references). In a Dominican codex, Sermones Dominicales (1456-1470), a Latin glossa explicitly says: "Et hoc vobis i.e. signatum vel pro signo Jel signum", where the correct and erudite Latin terms deserve the most attention. It is well known a fact that in Magyar Encyclopaedia... by János Apáczai Csere (1653) we could trace a highly developed classification and terminology of signs in Hungarian. The most striking feature is that the words used in Hungarian for semiosis are not from the common European (Graeco-Latin) vocabulary, but refer to an older strata in the language. Hungarian (TESZ II: 270) and Finno-Ugric etymological dictionaries (UEW I: 2, 91) agree that the Hungarian jel/jegy can be derived from the Finno-Ugric jälke (footprint), belonging thus to the vocabulary of the ancient culture of hunters (see Voigt 1990).

In the major Finno-Ugric languages we do not find such old words, used today as semiotic terms: the Finnish merkki or the Estonian märk (and märgisüsteem further on) are recently coined forms with non-Finno-Ugric background. In other Finno-Ugric languages the similar terms are quite new too. A similar situation can be observed also at the semantic development and recent status of terms denoting the 'scientific study of signs' in the Finno-Ugric per- 
spective. Following the development and terminology of international semiotics, the Estonian semiootika has been invented recently, as a term from the 1960 s, originated from the Russian terminology of the same time. Somewhat later the Finnish semiotiikka appeared, following the main international semiotic trends and terms. This term is from the Anglo-German-Russian tradition (not from the French one), and, despite the very close contacts of Finnish semioticians with the French schools, does not represent (with some exceptions) sémiologie. Slightly earlier the Hungarian szemiotika was used as a scholarly term. It came directly from Russian (better to say from the early works of the Moscow-Tartu School), but within an international frame of reference, and with some regard to older usage. The Hungarian equivalent (jeltudomány) is understandable, but it does not exist in everyday use. The Hungarian term finally belongs to the American (Peircian) tradition, but with Russian intermediary reasoning.

In other Finno-Ugric languages we could not find such a special term for semiotics or for the study of signs in general usage that would not be a direct translation from Russian.

One could repeat the fact that in the Finno-Ugric languages thus terms to designate 'the science of signs' are related to semiotic(s), rather than sémiologie (which is of course curious, if taking into account the specific scientific developments both on the paradigmatic scale and the connections on personal level between the scholars). It is an important task to describe the semantic development of the terms for 'semiotics' in all Finno-Ugric languages with a special emphasis on their origin and differences. Unfortunately, there have not been such summarizing attempts; so this is definitely an important task for the future.

As for contemporary humanitarian studies, then in Hungary only some years later than the Tartu-Moscow School was established in Estonia, by about 1968, structural studies in linguistics and literature, search for models in folklore, mass communication or cultural phenomena were grouped together into a special circle which was then marked by terminology of semiotics. Informal (but not persecuted) groups, projects, conferences and publications grouped on similarly. Since then semiotics in Hungary has been alive, and has gained a positive international response (see Voigt 1977). On the other hand there is no 'Hungarian School' of semiotics; however there have been established stabile connections with Hungarian semioticians who have been working in Yugoslavia, Romania, Czechoslovakia, United States, France, Italy, etc.

While the present article can treat the development of semiotics in Estonia, Finland and Hungary, it can not be as successful when trying to describe other Finno-Ugric cultures in which we do not know of any particular semiotic school or trend - at least by now and according to our information. However, in Debrecen (1990) and Jyväskylä (1995) international Finno-Ugric congresses Komi ethnographers and mythologists declined to semiotics. As N. Konakov has written at the 1992 Imatra International Summer Institute 
meeting, Komi (Zyrian) semiotics considers the works by A. Sidorov (from 1924 on), L. Gribova (from 1968 on), V. Semenov, N. Chesnokova and D. Nesanelis as its predecessors. In September 1991, the third all-republican meeting ("Death as a Phenomenon of Culture - Komi Seminar of Culture") was held in Syktyvkar. At the $11^{\text {th }}$ Annual Meeting of the Semiotic Society of Finland (Imatra, July 13-19, 1992) a session "Semiotics of Nature and Culture of the Komi (Zyrians)" was organized by J. Seppänen and N. Konakov. In the frame of that event Konakov declared their connection with the Tartu School. However, in the papers presented, the terminology of semiotics occurs very rarely, not giving thus the possibility for the reviewers to make the relevant Finno-Ugric comments (among the few articles by the Finno-Ugric authors representing semiotic viewpoint and simultaneously nations incorporated to the Russian, formerly the Soviet, cultural space, see Konakov 1993; Limerov 1993; Uljashov 1993; Shaparov 1993).

At least today it remains a secret, whether in the lost manuscript by G. Kuzebaj (1898-1937) from 1922-1925 on the Udmurt ornaments we could have found another (Udmurt) forerunner of Finno-Ugric ethnosemiotics.

\section{Finno-Ugric semiotics and its influence on the semiotic paradigm}

What about the Finno-Ugrians as a group of little nations to have their influence on the development of global semiotics? A simple and common sense answer would be: peripheral. However, this is also the key to analyzing any development of scientific paradigms in Kuhn's sense. In the development of semiotics, several Finno-Ugrians (as we first are to talk restrictedly about individuals in the philosophical terms of scholarly development) have been in the role of influencing the alternation of the paradigm as defined by the essence of the nucleus of the paradigm. The Hungarian T. A. Sebeok has undoubtedly served semiotics in its expansion to the object areas considered as nonexistent or peripheral in the mainstream of semiotics (see Sebeok's output 1942-1995; Deely 1995). The open contemporary (having of course the fundamental works by J. v. Uexküll from the beg. of the turn of the century in mind) inclusion of biological (and, in fact, biospheric in Vernadski's sense) phenomena into the scope of semiotics has demanded also review of the general metalanguage and terminological foundations of the nuclear elements of the paradigm as a whole. This development seems to be a classic example of the evolution of a scholarly discipline.

In connection with the biological aspects to be dealt by semiotics, but besides such an overall influential cooperation to semiotics, there can be brought forward also other kinds of examples concerning the dynamism between the center and the periphery of objects in a scientific paradigm. For example, it is a general truth that several peripheral phenomena including the savage from the cultural point of view (e.g. madmen, heathens) were not 
switched into scientific analysis of human culture (see e.g. C. Kluckhohn's view on 'culture as a theory'; Kluckhohn 1961: 25). So, while it is true that the development of psychology and psychiatry in a way helped also to widen the perspective of other disciplines studying man and his environment, there can probably be observed an even more coherent progress allied with the field of psychosemiotics. In this area it is expedient to mention Estonian scholars J. Valsiner and J. Allik whose well-known contribution is situated at the foundation stones of the field, especially when laying stress on the semiotic ingredient of it (Valsiner and Allik 1982). There are certainly other areas that do not belong directly to the mainstream of the semiotic discussion, but probably the Finno-Ugric presence can be noticed in several areas due to the specific contemporary history of these peoples. Of course, when talking about the general development of semiotics in terms of speaking of a discipline's development as an interaction between the central and peripheral elements, one can not escape both earlier contributions of the Finn E. Tarasti to musical semiotics from the 1970s onwards (in English see e.g. Tarasti 1979 and 1994) and his initiative excursions into philosophical, i.e. 'existential' semiotics (Tarasti, forthcoming).

\section{Semiotics and a Finno-Ugric culture: Finland}

Contemporary Finnish semiotics was in its nation-wide scale apparently born through the foundation of the Finnish Semiotic Society (1979). The first group of Finnish semioticians came from late French structuralism, but it was also in contact with the Tartu school. Its membership and the scope of interests grew fast, and by now Finnish semiotics is probably the best-organized nation-wide trend in Europe. The unusually dynamic growth of semiotics during recent twenty years in Finland (that can be followed through the journal of the Finnish Semiotic Society, Synteesi, from 1982 on) lead to the foundation of the International Semiotics Institute at Imatra, Eastern Finland, in 1988 - now one of the world's leading center in the field. During the recent years ISI has organized international summer schools of semiotics, and its contacts with Estonian, Hungarian Soviet/Russian, Nordic, American, French and other schools and individual semioticians are extensive. Semiotics in Finland is many faceted: semiotics of music, literature and theatre, film and art, semiotics of culture and personality. Symposia very often deal with the characteristics of Finnish people and culture. It is interesting to observe that, although they follow very contemporary themes and models (marketing, information theory, politics, gastronomy), for some traditional domains (as e.g. linguistics), there is a gap between them: traditional scholars in Finland do not use the vocabulary and ideas of semiotics (see also Voigt 1995).

The quick evolution of semiotics in Finland can be explained only on the basis of its Finno-Ugric roots - the semiotic approach in general has its firm basis in the Finno-Ugric mentality, first revealed by the fact that the main 
hero of Kalevala, Väinämöinen, was a sorcerer who by his wisdom and magic, and not by force, ruled over the world. The Finns have an inclination towards meditation and philosophical questioning (not to mention such later caricaturesque figures in the Finnish literature like Veikko Huovinen's "Havukka-ahon ajattelija"; see Huovinen 1952). On the other hand, semiotics in Finland was launched by the brothers Kaarle and Julius Krohn in the late nineteenth century, and completed in musical research by Ilmari Krohn, first professor of musicology at the Helsinki University. Their ideas for classifying the folklore, folktales, folk tunes were later adopted by the Russian formalists like V. Propp, and in music by B. Bartók and Z. Kodaly. When Propp was found among the French and American structuralists in the 1960s, the new discipline within semiotics, narratology, began. So there is a direct line leading from the Krohns to the entire rich area of narrative studies at the moment.

Moreover, the ties with Baltic semiotic traditions were important in the history of Finnish semiotics. If the first 'semiotician' in Finland was Henry Parland (1908-1929), a Finnish-Swedish poet, who wrote cultural essays as a kind of 'Barthes before Barthes', then his uncle Wilhelm Seseman (18841963), who was a half-Finn, has been considered the greatest philosopher in Lithuania whom even A. J. Greimas knew before his emigration.

These traditions were found when the Finnish semiotics, during its rapid rise in the 1980s, searched for a 'noble origin' and history of its own. But still a great part of semiotic research in Finland focuses on the Finnish or 'FinnoUgric' specificity albeit most semiotics exercised by the Finns attempts to be as universal as the science always should be.

\section{Semiotics and a Finno-Ugric culture: Estonia}

While it is clear that the role of the Hungarian and Finnish semioticians in determining the development of contemporary semiotics is hardly questionable, this can not be said of Estonian scholars. Beginning from J. von Uexküll up to the influential figures of cultural semiotics until very recently, one can only admit the role of Estonian cultural space as having favored the development of semiotic argumentation. Of course there can be listed several names whose output can be regarded as semiotic, but at a closer look we find their terminology loose and, probably in connection with the influence of German philosophical influence, ignorant of their contemporary semiotic treatments characterizable as already semiotics proper. A vague borderline between the use of culturological and culturo-philosophical general bias of expressing views on cultural developments, and modern attitude marked by more coherent and already at least presemiotic argumentation style can be associated with the (largely unknown both for Estonian and international audience) works of Uku Masing (1909-1985) that are extensively being printed only nowadays (e.g. Masing 1993, 1995). Thus it seems that, when trying to outline the merits of Estonia in the new complex of studies in Finno-Ugric semi- 
otics and if wanting to delineate the semiotic features, structures and developments of this particular cultural area, there are exactly the wider linguistic, cultural and national aspects to be analyzed.

When speaking of the field of Finno-Ugric semiotics, it seems necessary to differentiate between two paradigmatic aspects: on the one hand we can speak of the metalevel and 'semiotics proper' in the disciplinary sense of the expression. On the other hand we should probably consider also semiotic development and the development of semiotic conceptions and viewpoint at the sociocultural scale of Finno-Ugrians in the sense semiotic interpretations are used in everyday cultural discourse. Such cultural discourse includes different topics beginning from issues pertaining to cultural and national identity to e.g. public criticism of cultural life (discussions on exhibitions, presentation of a given culture and socium internationally, etc.). It has often been argued that such topics belonging to the core of cultural identity are not discussed among the relevant society and that the cultural practices in which these core items manifest themselves, are largely automatic. However, it would probably be useful to differentiate between dissimilar techniques of building and using the so-to-speak habitual doxic universe (see Bourdieu's treatment of the theme; Bourdieu 1992), and also between different items belonging to it. In more isolated and in the so-called primitive cultures the non-questioned status of the cultural nucleus concerns both the cultural units it comprises, and also norms regulating the usage of these units. In other cultures that are subjected to more intense international and intercultural communication, it seems to be inevitable that the communicative habits and cultural life style is systematically brought to conscious reflective practice in order to maintain a stable position in intercultural interaction. Therefore it seems that a considerable amount of cultural units belonging to the nuclear elements of the sociocultural reality are to be switched into active semiotic use to keep the national and cultural identity discourse integral.

Due to the specific geopolitical location of Estonia there has always been a strong need for the above described intracultural dialogue to facilitate preservation of cultural self-awareness. Estonian military and political history have urged cultural self-determination as related to the others also in terms of what has been considered as forming the core of cultural identity. Therefore there have been brought to discussion the elements and semiotic systems regarded as culturally the basic ones on the one hand, and semiotic techniques applied to the usage of them on the other hand. The overall Estonian public semiotic activity reached its first contemporary peak in the middle of the $19^{\text {th }}$ century during the first period called National Awakening. Probably greatly due to the suppression of the Estonian language by different foreign powers that had been ruling the Estonian area, a major attention has been paid to language from that stage of cultural identity discourse onward. The role of language as a means of mediating this discourse and further publication of the latter was recognized immediately, and so the status of language and written documents started to gain special attention and authority. It was Carl Robert 
Jakobson (1841-1882), one of the few decisive figures in the process of forming the shared consciousness of individuals living in the territory of the present Estonia, who articulated the central position taken by language in the national and cultural identity. In his Three Speeches on/for Fatherland (18681870) Jakobson expressed quite a characteristic view on language as "the foremost thing, however, from which a nation's degree of mental education can be recognized" (Jakobson 1991: 21). Thus language is attributed a kind of metacultural role - "Language is the vehicle of a nation's education, and thus it is what gives birth to its [the nation's] fine order and freedom, it is the most precious heritage of a nation" (ibid.). In a way then we can see that language and a culture, and a culture as semiotically definable as a signifying order (the term used by M. Danesi and P. Perron; Danesi 1998, Danesi and Perron 1999) are indeed related to the study of cultural spaces as related to the original concept of culture area as developed by P. Vidal de La Blache and H. Mackinder (see e.g. Vidal de La Blache 1926). Cultural traits by which cultural areas can be determined anthropologically are a type of manifestation of the signifying order, which is largely configured by natural language (following this logic, see Randviir, forthcoming). Thus one could see evidence of organizing semiotics on the metalevel also as a study of different signifying orders that can be classified on the basis of language groups, and it will probably imply more coherent studies than those arranged according to the specific individual categories of objects of research.

Having mentioned Jakobson as one of the most important public figures for the formation of the Estonian nation, we simultaneously witness the beginning of a tendency to determine the essence of the Estonian as distinguishable from the others through opposition. There have been diverse bases for building the relevant system of opposition(s), e.g. according to the national principle (the Estonian vs. the Russian or the German), religious aspects (Estonians as religious people vs. Estonians a pragmatic profane people; Estonians as having their own pagan belief vs. Estonians as Christians, etc.). It is perhaps typical that national and cultural self-definition as based on oppositional character gains actuality during such decisive periods or in such cultural situations that involve more factors directly influencing cultural behavior. Stagnation in cultural identity discourse can be noticed during especially calm political environment, be such tranquility due to independent well being of a nation (in case of Estonia during the approximate period between 1920s1930s), or due to forced political situations (e.g. the Soviet period of Estonia). Similarly it seems to be characteristic that reflections on cultural identity have been active in the Diaspora of Estonian culture. Hereby it is convenient to refer to Oskar Loorits, a cultural philosopher in matters pertaining to outlining what constitutes the Estonian culturally and psychologically. He is a suitable representative of the Diaspora in Sweden where there actualized several cultural oppositions needed to be solved (Estonia vs. Estonian SSR, Estonia vs. USSR, Estonia vs. Russia, Estonia vs. Sweden, etc.). It seems quite characteristic that due such oppositional plentitude that lead to a demagogical dead- 
lock, Loorits finally reduced the binaries to the contrast between the great nations and the small ones, comparing the history of the former to a "motion picture with exciting scenes, shocking conflicts and surprising tricksolutions" (Loorits 1951: 14). Estonian history, on the other hand, is "a monumental mosaic picture compiled of bits and pieces collectively by all generations that is enlivened and spiritualized by the harmonious synthesis of man and nature up to cognition of the divine not only in oneself, but everywhere" (ibid.). Loorits thus makes a distinction between the great and the smaller nations on the basis of different degrees of cultural reflective (rather than actual) activity, stating that peoples small in number are to stabilize their culturo-historical development by continuous conceptual return to the past, because the "essence of a nation lies in its past" (Loorits 1951: 10). Such reflective practice helps to minimize and soothe potential oppositional situations inside the given culture; homogenization of history through its transfer into a coherent cultural tradition involves swap of stress from individuals and their merits to the nation as an integral agent in the historical process. A similar look has been taken by U. Masing who, discussing about the mentality of the Estonians, conjoins the linguistic and grammatical (e.g. absence of the future tense and gender), geographical (as concerning the landscape) and general spiritual features of Estonians under a vague common denominator of the "unicellular amoeba" that is growing in all directions in its integral development (from the article On Estonian Spirit included in Masing 1993: 163).

While distinctive oppositions have been characteristically set on the basis of 'big vs. small', there have also been made trials to switch the Estonian culture into a wider multicultural oicoumene, probably in order to inscribe a more confident position of the nation in intercultural communication. These attempts have usually been made on either linguistic or geographical basis, connecting the latter with the cultural dimension. Attempts to define cultures in spatial, linguistic and other terms have been made in both intracultural dialogue on identity, and also on the metalevel. It is possible to differentiate between two major trends in suchlike association of the Estonian cultural space with a wider context: on the one hand there is the linguistic approach, and on the other hand we can find the geographic one. Needless to repeat that neither of them appeals to linguistic or geographic features only, but rather treat the subject in the terms of cultural areas. The linguistic division has the expression 'Finno-Ugric' as the common denominator, while the geographic bias has used the term 'Balto-Skandia'. The Finno-Ugric trend can well be illustrated by the works of the already mentioned cultural philosopher $\mathrm{O}$. Loorits who's approach can, in turn, be viewed as following the ideas of classical cultural anthropology in its manner of explaining the substantial nature of cultures and cultural individuality (see e.g. C. Kluckhohn's classical treatment; Kluckhohn 1961: 20-40). Loorits describes the common past of the Finno-Ugric peoples as having its origins in the 'Uralian culturehood' that, as an integral whole of life-style and behavioral patterns, together with environmental features, was imprinted into the collective mind of all the Finno-Ugric 
peoples. The gradually more and more local settlement induced the kinship consciousness that was essentially molded by natural conditions dominated by the forest (Loorits 1951: 35). Such mentality shaped by the woodland seems to be another macrosignified manifesting itself in other Finno-Ugric cultures as well (see e.g. Tarasti 1999). Hereby we will not go into deeper analysis of the semiotic features based on the Uralian common cultures that, according to Loorits, must be considered as essential also nowadays during the process of both primary and secondary socialization (see Loorits 1953); this is - as at leat a reflective task - for the future.

The other general view on the relationships between the Finno-Ugric cultures and their kinship with other Scandinavian and Baltic cultures is perhaps best represented by the works of the Estonian geographer E. Kant. His views on the Finno-Ugric unity (from the Estonian viewpoint) represent schemes of geographic proximity between (only few) Finno-Ugric peoples. In Kant's view Estonia belongs environmentally and thus also culturally to the geographic and cultural area of Balto-Skandia (cf. W. Ramsay's Fenno-Skandia). It is in a way interesting that Kant's understanding of territorial structures was functional (which, in fact, was common to his era) - one of the main factors in the case of his description of the unity of the Balto-Skandic space being religious homogeneity in the face of Christianity (cf. Loorits and many other thinkers who have religiously conjoined the Finno-Ugric peoples with having their own unique religion connected with their specific life-style). Since the anthropo-ecological view on such territorial and cultural unified semiotic space like Balto-Skandia, as widely treated by E. Kant (see e.g. Kant 1934, 1935), has recently been given a historical and theoretical overview (Buttimer 1994), the matter needs no further discussion in detail in the current context.

Whereas the above hopefully endorsed of contributions of certain FinnoUgrians to the general advance of semiotics, this is obviously just a minor aspect the Finno-Ugrian semiotics should concentrate on. Especially the position of Estonian cultural space seems to point at that it is not only the individuals are to be included into suchlike semiotic research, but rather the respective culturo-national factors favoring (or not) semiotic development.

\section{Filling up Finno-Ugric semiotic studies in the future}

International cooperation among Finno-Ugric semioticians is not a new phenomenon. They have known of each other, and since very many years Finnish and Hungarian semioticians, Finnish and Estonian semioticians regularly meet by combining these meetings. In May 1997 there was the 19th FinnishHungarian semiotic symposium in Budapest, and between November 26-28 in 1998 the $20^{\text {th }}$ symposium in Berlin. There exist a few reports also about the previous meetings (see Broms 1995, 1997). Following this line in a more extensive scale, a primary task for the Finno-Ugric Semiotics Association is first of all facilitation of information exchange that perhaps can be coordi- 
nated by the ISI, together with the new association, in Imatra. Through symposia and publications the Finno-Ugric semiotics is to reach to a "handbook" of itself (whether in a concrete written form or not) in order to bring the theme clearly also to wider international semiotic dialogue, since general international semiotics has been relatively unaware of it. Until now Finnish, Hungarian and Estonian (the latter as having been included to 'semiotics in the USSR') semiotics have been represented in one of the best handbooks of the recent history of semiotics (Sebeok and Umiker-Sebeok 1986), but as these chapters were written more than a decade ago, a new (or at least updated) version, with regards to as many Finno-Ugric peoples as possible, should be composed.

From the 1960s to the 1990s there was the "new golden age" of semiotics in Europe, America and elsewhere. Today semiotic institutions have gained certain stability, even though most of the pioneer semioticians have passed away. Now we witness the "silver age" of international semiotics, as new centers or schools appear (other ones, e.g. from France, disappeared). The Tartu-Moscow school in its original form does not exist any more. Hungarian semiotics remained as loose a formation as it was ever. Finnish semiotics has become one of the leading groups in the whole world. The growing trend of the Finnish tradition (it is hereby noteworthy that the rapid evolution of it came along with the formation of an institutional structure, as mentioned above), and also the re-organized practice in Estonia, point, in fact, at another possible development. While the mentioned "golden age of semiotics" was, all in all, still determined by individual works and scholars, the contemporary stage of semiotic studies clearly has integration as a common denominator. This integration concerns several semiotic (sub)paradigms, viewpoints, objects of study, scientific communities and individuals. Cooperative projects (e.g. those initiated in Finland) imply studying native or local cultural objects and themes internationally, just as well as inspection of cultural phenomena involves application of diverse semiotic tool-kits that were not considered as unitable even recently. Therefore, hoping that Finno-Ugric semiotics will add qualitatively new perspectives to the study of national cultures in their intertwined nature, one could also look forward to its contribution to bringing clarity to the overall integrated net of semiotic objects and metalanguages in general.

\section{References}

Bourdieu, Pierre 1992. The Logic of Practice. Cambridge: Polity Press.

Broms, Henri 1995. Valami más: Proceedings of the Finno-Hungarian Semiotic Symposia 1985-95 Helsinki-Budapest. Helsinki.

- 1997. Valami egészen más: Proceedings of the Finno-Hungarian semiotic symposia 1996-97; Vol. 2. Helsinki. 
Buttimer, Anne 1994. Edgar Kant and Balto-Skandia: Heimatkunde and regional identity. In: D. Hooson (ed.), Geography and National Identity. The Institute of British Geographers Special Publication Series; 29: 161-183. Oxford, Cambridge, Massachusetts: Blackwell.

Danesi, Marcel 1998. Sign, Thought, and Culture: A Basic Course in Semiotics. Media, Communications and Culture Studies. Toronto, Ontario: Canadian Scholars' Press.

Danesi, Marcel; Perron, Paul 1999. Analyzing Cultures: An Introduction and Handbook. Advances in Semiotics. Bloomington: Indiana University Press.

Deely, John (ed.) 1995. Thomas A. Sebeok bibliography 1942-1995. Arcadia bibliographica virorum eruditorum; 15. Bloomington: Eurolingua.

Huovinen, Veikko 1952. Havukka-ahon ajattelija. Porvoo: WSOY.

Jakobson, Carl R. [1870] 1991. Kolm isamaa kõnet. Kriitiline väljaanne käsikirjast. Tallinn: Eesti Raamat.

Kant, Edgar 1934. Estlands Zugehörigkeit zu Baltoskandia. Publicationes Universitatis Tartuensis Oeconomico-Geographici; no. 9. Tartu.

- 1935. Bevolkerung und Lebensraum Estlands. Ein Anthropoökologischer Beitrag zur Kunde Baltoskandias. Tartu: Akadeemiline Kooperatiiv.

Kluckhohn, Clyde 1961. Mirror for Man: A Survey of Human Behavior and Social Attitudes. Greenwich: Fawcett.

Konakov, Nikolai I. 1993. Die Kalendersymbolik des Uralischen Heidentums. In: Tarasti, E. (ed.), On the Borderlines of Semiosis. Acta Semiotica Fennica II. Publications of the International Semiotics Institute at Imatra, 4: 121-125.

Limerov, P.F. 1993. The reconstruction of cosmological ideas of the Komi. In: Tarasti, E. (ed.), On the Borderlines of Semiosis. Acta Semiotica Fennica II. Publications of the International Semiotics Institute at Imatra, 4: 127-130.

Loorits, Oskar 1951. Eestluse elujõud. Enskede: Tõrvik.

Loorits, Oskar 1953. Pagulaskodude kasvatusmuresid. Vadstena: Tõrvik.

Masing, Uku 1993. Vaatlusi maailmale teoloogi seisukohalt. A. Lääts, toim. Tartu: Ilmamaa.

- 1995 Eesti usund. A. Lääts, toim. Tartu: Ilmamaa.

Randviir, Anti forthcoming. The nationalism of signs. In: Tarasti, E. (ed.), Acta Semiotica Fennica.

Sebeok, Thomas 1942-1945. See Deely 1995.

Sebeok, Thomas and Umiker-Sebeok, Jean (eds.) 1986. The Semiotic Sphere. Topics in contemporary semiotics. New York: Plenum Press.

Shapirov, Valerij 1993. The zoomorphic code in the symbolism of children's furniture of the Komi people. In: Tarasti, E. (ed.), On the Borderlines of Semiosis. Acta Semiotica Fennica II. Publications of the International Semiotics Institute at Imatra, 4: 139-146.

Synteesi: Taiteidenvälisen tutkimuksen aikakauslehti (1982-) E. Tarasti (päätoim.). Helsinki.

Tarasti, Eero 1979. Myth and Music: A Semiotic Approach to the Aesthetics of Myth in Music especially that of Wagner, Sibelius and Stravinsky. Approaches to Semiotics; 51. The Hague: Mouton.

- 1994. A Theory of Musical Semiotics. Advances in semiotics. BloomingtonIndianapolis: Indiana University Press. 
- (Forthcoming). Existential Semiotics. Advances to Semiotics. BloomingtonIndianapolis: Indiana University Press.

- ed. 1999. Snow, Forest, Silence: The Finnish Tradition of Semiotics. Acta Semiotica Fennica VII. Imatra, Bloomington: Indiana University Press.

Uljashov, Oleg 1993. Semantik der Metalle in der Weltanschauung des KomiVolkes. In: Tarasti, E. (ed.), On the Borderlines of Semiosis. Acta Semiotica Fennica II. Publications of the International Semiotics Institute at Imatra, 4: 131-137.

Valsiner, Jaan and Allik, Jüri 1982. General semiotic capabilities of the higher primates. In: Key, M.R. (ed.), Nonverbal Communication Today: Current Research. Berlin, New York: Mouton, 242-257.

Vidal de La Blache, Paul 1926. Principles of human geography. E. de Martonne, ed. New York: H. Holt and Company.

Voigt, Vilmos 1977. Bevezetés a szemiotikába. Budapest.

- 1990. Auf den Spuren einer uralischen (Vor)Semiotik. Specimina Sibirica III: 241-250.

- 1995. The taste of Finnish semiotics. Semiotica 106(3/4): 301-306.

Voigt, Vilmos; Balázs, Géza (eds.) 1998. A magyar jelrendszerek évszázadai. Budapest. 